\title{
APLIKASI MODULASI DIGITAL FSK (FREQUENCY SHIFT KEYING) PADA TELEMETRI SUHU
}

\section{Martina Pineng}

\author{
Teknik Elektro
}

Universitas Kristen Indonesia Toraja

Jl. Nusantara No.12 Makale 91811, Tana Toraja

mpineng@gmail.com

\begin{abstract}
Abstrak
Dengan munculnya teknologi telemetri suhu dapat memberikan kemudahan dalam mengukur suhu jarak jauh, dengan pemantauan dari tempat yang aman dan memungkinkan. Aplikasi telemetri suhu biasanya diterapkan pada pemantauan suhu gunung berapi, pemantauan suhu pada peleburan baja, pemantauan cuaca yang tidak memungkinkan manusia untuk melakukan pengukuran secara langsung pada jarak yang dekat. Pengiriman informasi pada telemetri dapat dilakukan secara wireline maupun wireless. Teknik pengiriman informasi merupakan salah satu yang menentukan kehandalan sistem telemetri apalagi jika pengiriman informasi dilakukan secara wireless. Selain itu, pengolahan awal sinyal dan teknik modulasi yang dipilih akan sangat menentukan kehandalan sistem telemetri tersebut. Pada review ini dijelaskan perancangan perangkat keras telemetri dengan modulasi FSK (frequency Shift Keying)- FM (Frequency Modulation). Dalam perancangan telemetri suhu ini dibagi dalam dua kategori yaitu bagian pemancar dan bagian penerima. Teknik modulasi awal dilakukan secara FSK kemudian dilanjutkan modulasi secara FM. Perancangan telemetri suhu ini tidak lepas dari kinerja sensor suhu LM35 beserta perangkat-perangkat lainnya seperti mikrokontroler dan bahasa pemogramanVisual Basic versi 6. Pada penerima hasil pengukuran ditampilkan pada layar monitor PC sehingga dibuat juga program antarmuka untuk keperluan tersebut. Hasil pengujian menunjukkan bahwa sistem ini mampu bekerja pada jarak maksimum 700 meter. Pada pengukuran terdapat perbedaan pada pengkonversian suhu oleh sensor LM35 yang dipakai dibandingkan dengan
\end{abstract}


termometer sebesar $1,2^{\circ} \mathrm{C}$ Kata kunci : telemetri, sensor, suhu, frekuensi, dan sinyal.

\section{PENDAHULUAN}

Sistem telemetri suhu adalah salah satu sistem untuk mengukur suhu jarak jauh. Hal ini sangat diperlukan karena pertimbangan keselamatan dan efisiensi. Sistem ini dapat dipakai untuk pengukuran di tempattempat yang sulit untuk dijangkau atau berbahaya bagi keselamatan manusia, seperti gunung berapi, gua, lembah, atau di tempat peleburan baja, sehingga tidak memungkinkan bagi manusia untuk melakukan pengukuran dan pengamatan suhu secara langsung atau dari dekat. Selain itu, pada kegiatan pemantauan cuaca yang dilakukan terusmenerus, dimana salah satu parameternya adalah suhu, dapat dilakukan di tempat yang lebih aman dan nyaman [1].

Dalam review ini dijelaskan tentang perancangan perangkat keras yang mendukung telemetri suhu dengan modulasi digital FSK (Frequency Shift Keying). Adapun komponen-komponen yang dipakai antara lain: sensor suhu tipe LM35, peralatan pemancar modulasi frekuensi dengan frekuensi $110 \mathrm{MHz}$, mikrokontroler AT89C51 dan juga PC untuk menampilkan hasil pengukuran.

\section{DASAR TEORI}

\subsection{Sistem Telemetri}

Telemetri berasal dari kata "Tele" yang berarti jauh dan "Metri" yang berarti pengukuran. Dengan demikian telemetri adalah suatu sistem komunikasi untuk transfer data pengukuran jarak jauh yang menggunakan media transmisi sebagai carrier data tersebut. Dengan kata lain dapat dikatakan bahwa telemetri merupakan suatu proses komunikasi secara otomatis yang digunakan untuk mengukur dan mengambil data pada suatu lokasi yang letaknya jauh untuk ditransmisikan ke pusat pengolahan data. Beberapa hal yang perlu diperhatikan dalam telemetri adalah teknik modulasi dan saluran transmisi. Modulasi 
merupakan proses konversi sinyal informasi menjadi suatu gelombang sinus, atau penumpangan suatu sinyal (sinyal informasi) ke sinyal pembawa (carrier). Ada beberapa macam teknik modulasi [3].

\subsection{Sensor Suhu LM35}

Sensor adalah jenis tranduser yang digunakan untuk mengubah besaran mekanis, magnetis, panas, sinar, dan kimia menjadi tegangan dan arus listrik. Sensor sering digunakan untuk pendeteksian pada saat melakukan pengukuran atau pengendalian.

Sensor suhu tipe LM35 merupakan sebuah IC yang menggunakan chip silikon untuk elemen sensor. IC LM35 dapat memberikan tegangan keluaran (output) yang berubah-ubah secara linier seiring dengan perubahan suhu (temperatur) yang juga terjadi secara linier. Seperti sensor pada umumnya, sensor suhu LM35 bekerja berdasarkan perubahan suhu yang dialami oleh material sensor yang muncul dalam bentuk keluaran berupa tegangan listrik [3].

LM 35 memiliki kelebihan-kelebihan sebagai berikut : dikalibrasi langsung dalam celcius; memiliki factor skala linear $+10.0 \mathrm{mV} /{ }^{\circ} \mathrm{C}$; memiliki ketepatan $0,5^{\circ} \mathrm{C}$ pada suhu $+25^{\circ} \mathrm{C}$ seperti terlihat pada gambar 1 ; jangkauan maksimal suhu antara _55 sampai $+150^{\circ} \mathrm{C}$; cocok untuk aplikasi jarak jauh; harga yang cukup murah; bekerja pada tegangan catu 4 sampai 30 Volt; memiliki arus drain kurang dari $60 \mathrm{uA}$; pemanasan sendiri yang lambat (low self-heating), $0,08^{\circ} \mathrm{C}$ di udara diam; ketidaklinearan hanya sekitar $\pm 1 \_4{ }^{\circ} \mathrm{C}$; dan memiliki impedansi keluaran yang kecil, 0,1 W untuk beban $1 \mathrm{~mA}$

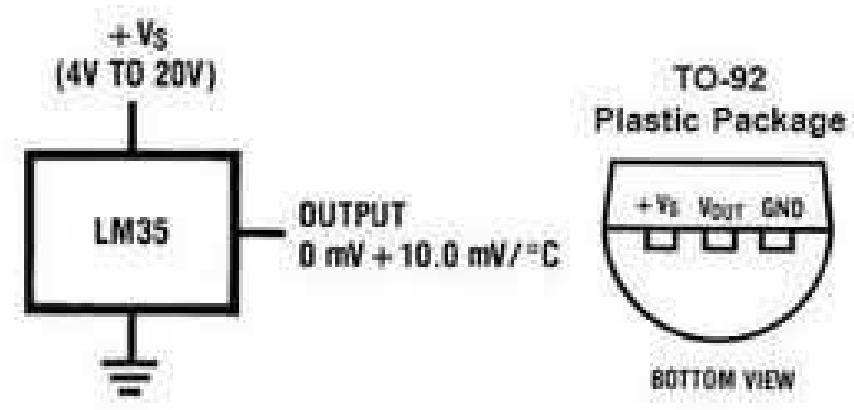

Gambar 1. Sensor suhu LM35 Grafik hubungan akurasi terhadap suhu untuk LM35 ditunjukkan oleh gambar 2. 


\section{Accuracy vs. Temperature (Guaranteed)}

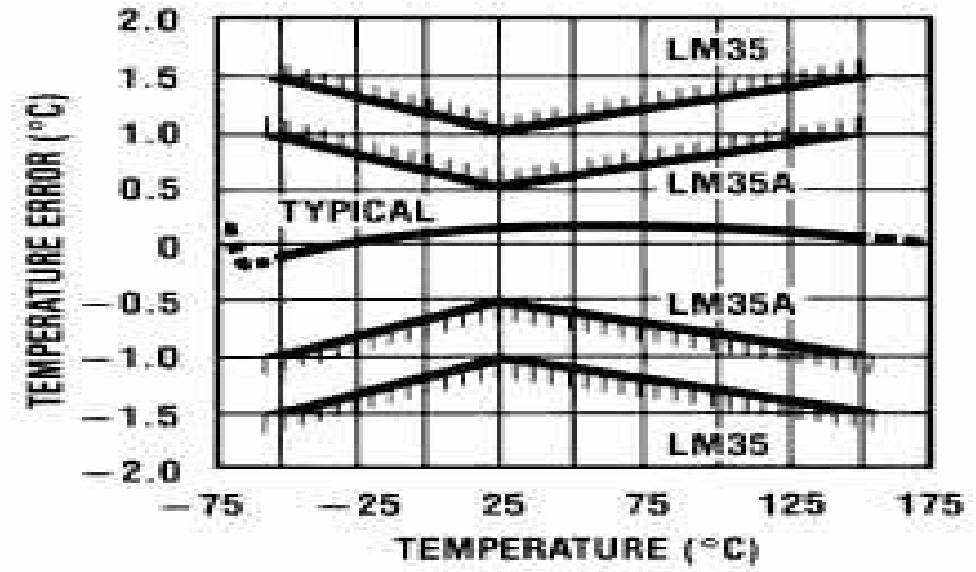

Gambar 2. Grafik hubungan akurasi terhadap suhu untuk sensor LM35 [5]

\subsection{Pengubah Analog ke Digital (ADC)}

Dalam review ini digunakan ADC0804. Gambar 3 menunjukkan susunan kaki ADC tersebut. Beberapa karakteristik ADC0804 adalah sebagai berikut:

- Memiliki 2 masukan analog : Vin (+) dan Vin(-) sehingga memperbolehkan masukan selisih (diferensial). Dengan kata lain, tegangan masukan analog yang sebenarnya adalah selisih dari masukan kedua pin [ analog $\operatorname{Vin}=\mathrm{Vin}(+)$ - Vin(-) ]. Jika hanya satu masukan maka Vin(-) dihubungkan ke ground. Pada operasi normal, ADC menggunakan $\mathrm{Vcc}=+5 \mathrm{~V}$ sebagai tegangan referensi, dan masukan analog memiliki jangkauan dari 0 sampai $5 \mathrm{~V}$ pada skala penuh.

- Mengubah tegangan analog menjadi keluaran digital 8 bit. Sehingga resolusinya adalah $5 \mathrm{~V} / 255=19.6 \mathrm{mV}$

- Memiliki pembangkit detak (clock) internal yang menghasilkan frekuensi $\mathrm{f}=1 /(1,1 \mathrm{RC})$, dengan $\mathrm{R}$ dan $\mathrm{C}$ adalah komponen eksternal.

- Memiliki koneksi ground yang berbeda antara tegangan digital dan analog. Kaki 8 adalah ground analog. Pin 10 adalah ground digital. 


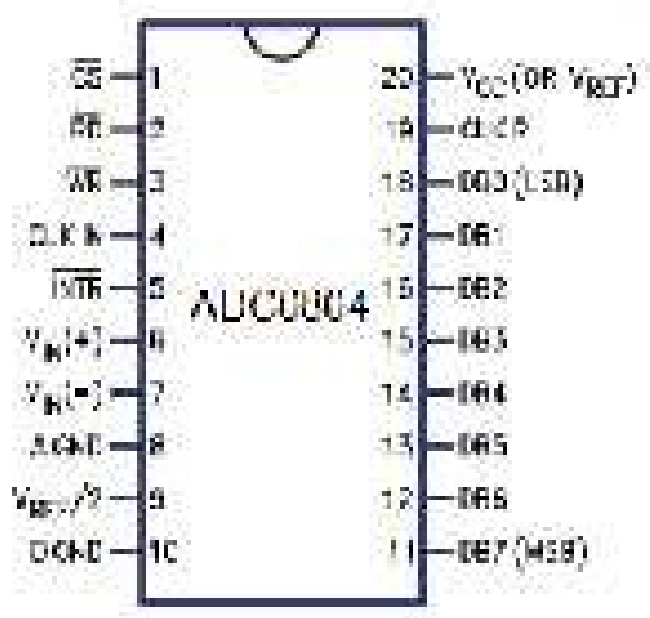

Gambar 3. Susunan kaki ADC 0804

\subsection{Multivibrator Astabil dengan IC555}

IC 555 merupakan IC pewaktu dengan keluaran TTL yang dapat beroperasi dengan berbagai mode. Keluarannya adalah gelombang kotak yang terus berosilasi pada dua level tegangan dengan jarak waktu tiap level tegangan yang ditentukan oleh nilai $\mathrm{R}$ dan $\mathrm{C}$. Jarak waktu tersebut disimbolkan dengan $\mathrm{t} 1$ dan $\mathrm{t} 2$, dan periode $\mathrm{T}$, yang ditunjukkan oleh gambar 4. Persamaan yang digunakan adalah :

$t 1=0.693 R B C$

$t 2=0.693(R A+R B) C$

$T=t 1+t 2$

Sedang hal yang harus diperhatikan adalah untuk nilai RA1 kÙ, RA + RB 6.6 MÙ, dan C 500 pF

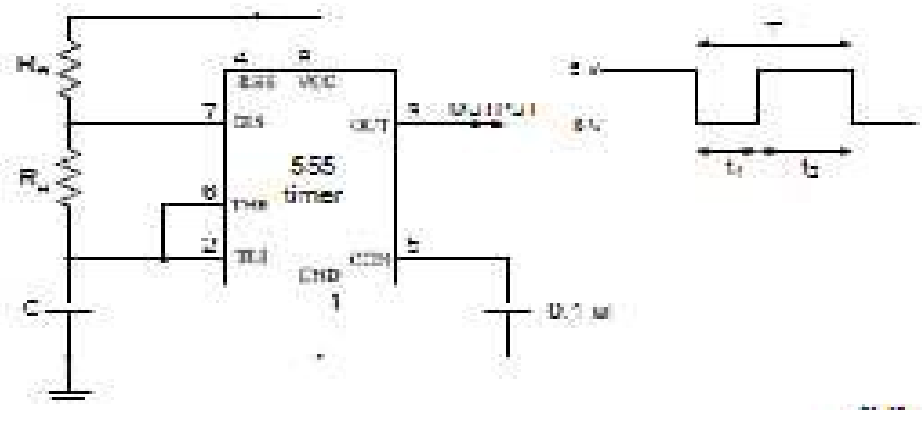

Gambar 4. IC555 sebagai multivibrator astabil 


\subsection{Modulasi FSK (Frequency Shift Keying)}

Modulasi frekuensi adalah sistem pemodulasi yang mengubah frekuensi isyarat pembawa sebanding dengan frekuensi sesaat isyarat pemodulasi, sementara amplitudo dipertahankan tetap. Dalam modulasi FSK (Frequency Shift Keying), isyarat pemodulasi berupa aliran pulsa biner yang bervariasi diantara dua arah tegangan diskret [2]. Rumus umum untuk sebuah isyarat FSK (Frequency Shift Keying) biner adalah:

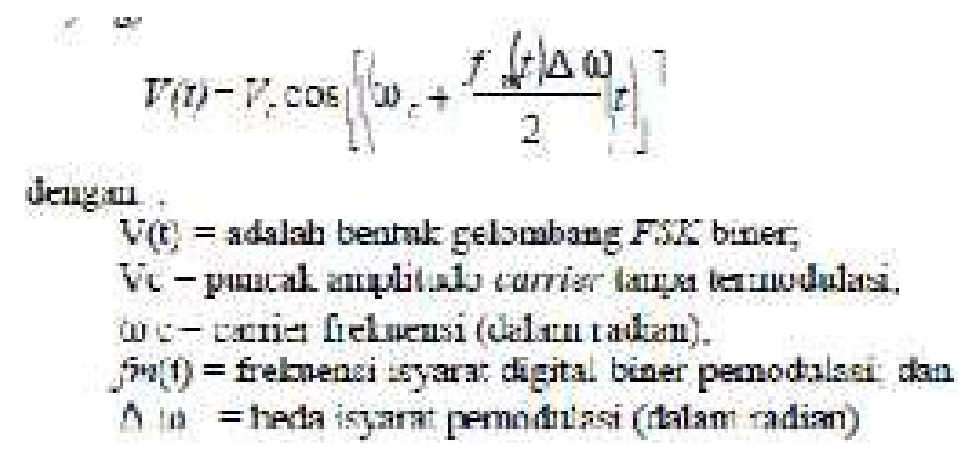

Keluaran modulator FSK (Frequency Shift Keying) adalah suatu frekuensi tertentu yang sudah ditentukan. Sesuai dengan perubahan isyarat data masukan biner dari logika 0 ke logika 1, atau sebaliknya, keluaran FSK (Frequency Shift Keying) bergeser diantara dua frekuensi yaitu suatu mark frekuensi untuk logika 1 dan suatu space frekuensi untuk logika 0. Suatu FSK biner secara sederhana diberikan seperti gambar berikut.

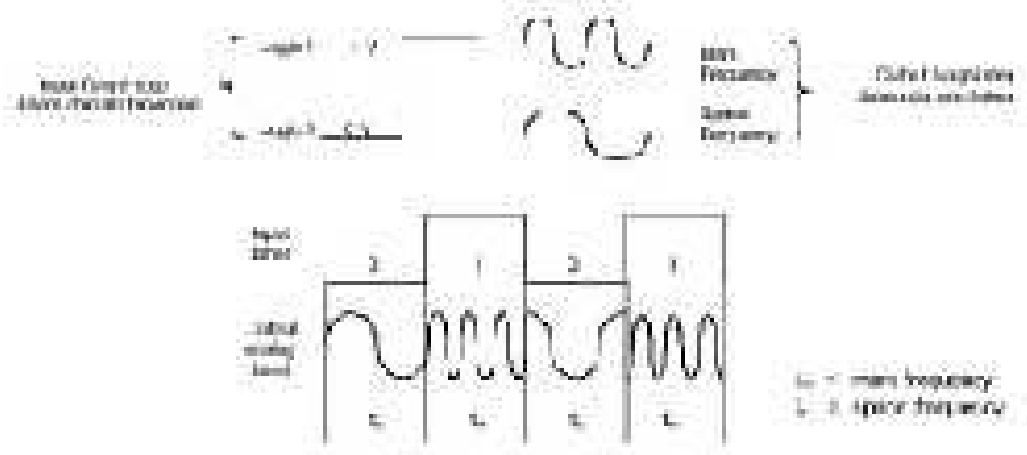

Gambar 5. Sistem modulasi FSK biner 


\subsection{Mikrokontroler AT89C51}

AT89C51 adalah mikrokontroler keluaran Atmel dengan 4 Kbyte flash PEROM (Programmable and Erasable Read Only Memory). AT89C51 merupakan memori dengan teknologi nonvolatile memory, yaitu isi memori tersebut dapat diisi ulang ataupun dihapue berkali-kali. Memori ini biasa digunakan untuk menyimpan instruksi bertstandar MCS-51 sehingga memungkinkan mikrokontroler ini bekerja dalam mode single chip operation yang tidak memerlukan external memory yang berfungsi untuk menyimpan source code tersebut. AT89C51 mempunyai 40 kaki, 32 kaki di antaranya adalah kaki untuk keperluan port paralel. Satu port paralel terdiri dari 8 kaki sehingga membentuk 4 buah port yang masing-masing dikenal sebagai Port-0, Port-1, Port2, dan Port 3.

\begin{tabular}{|c|c|c|c|c|c|c|c|}
\hline & & & & & & & \\
\hline Agrtotay & POO & 5. & 1 & 40 & $\square$ & RAS & (a)-cos \\
\hline IT1 & $r=3$ & $\therefore$ & 2 & $\mathrm{IB}$ & प1 & $F a_{1}$ & MLKC 13 \\
\hline 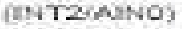 & $F=2$ & $\square$ & 3 & $\mathrm{AB}$ & 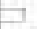 & $P A 2$ & FDACZ: \\
\hline Acromin & $p=1$ & II & 4 & 97 & \pm 1 & Finב & AnCuss \\
\hline 4ES & $\mathrm{FeA}$ & II & 5 & $3 \mathrm{~s}$ & $\square$ & Pont & MDE 4 \\
\hline (r.tosid & pess & r. & $\mathrm{a}$ & 35 & $\square$ & rAS & $A D C 5$ \\
\hline musos & $1=-06$ & i. & $F$ & $3=$ & $\square$ & $F a$ : & $A D=3$ \\
\hline $18+4$ & $1+a$ & $\theta$ & $\mathrm{a}$ & 33 & E & $P A 7$ & $A D C T$ \\
\hline FE & ESET & $B$ & 9 & 32 & ㅍ. & $\Delta F: F F$ & \\
\hline & Yco & $\theta$ & 10 & $\geq 1$ & 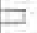 & GhD & \\
\hline & and & 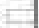 & 17 & ma & 5 & AvCo & \\
\hline & The & 18 & 12 & $2 \pi$ & [a & $\mathrm{PCl}$ & [tosstis] \\
\hline & $\mathrm{T}+\mathrm{k}=\mathrm{I}$ & $\square$ & 13 & 21 & 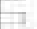 & poss & itoros:1 \\
\hline (PAXD) & Pod & 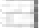 & 14 & \pm 2 & E & pres & 7701 \\
\hline$[T \times D$ & PDi & in & 15 & $2 a$ & 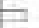 & $\mathrm{HC}_{-}$ & Tिä \\
\hline ginta: & $+5 \%$ & E & 10 & 26 & 피 & PCP & ThES \\
\hline GRII 1 & PLiz & t) & 17 & 2.1 & 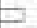 & $P C 2$ & TTOKI \\
\hline DOCIF & Prou & $\Delta$ & 10 & 23 & 5 & Pet & ISLM \\
\hline $10 \mathrm{cos}, \mathrm{m}$ & PDE & 10 & 19 & 22 & 4 & $\mathrm{TeO}$ & $790-1$ \\
\hline acrit: & PDE & t? & 20 & 21 & $\square$ & FDT & $10 x$, \\
\hline
\end{tabular}

Gambar 6. Mikrokontroler AT89C51

\section{PERANCANGAN}

Perancangan sistem telemetri suhu ini terdiri dari 2 bagian,yaitu bagian pengirim dan bagian penerima.

\subsection{Bagian Pengirim}

Bagian pengirim ini terdiri dari sensor LM35, pengkondisi sinyal, pengubah analog ke digital (ADC), mikrokontroler sebagai pengubah data paralel 
menjadi serial UART, pemodulasi pengunci pergeseran frekuensi (FSK), pembangkit sinyal sinus sebagai sinyal penanda, dan pemancar modulasi frekuensi.

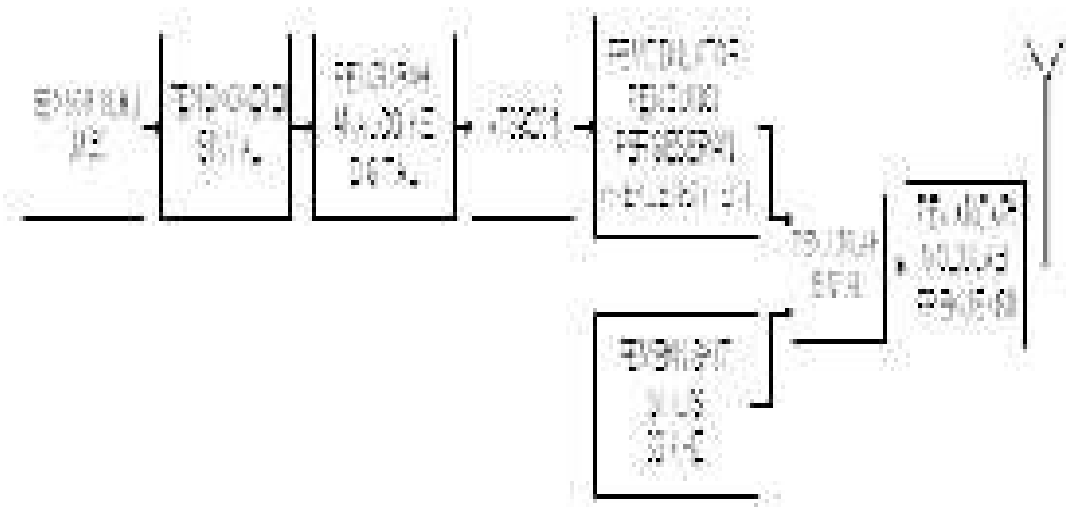

Gambar 7. Blok diagram pengirim [4]

\subsubsection{Sensor Suhu LM 35}

LM 35 memiliki jangkauan maksimum antara $-55^{\circ} \mathrm{C}$ sampai dengan $150^{\circ} \mathrm{C}$ jika dikonfigurasikan seperti gambar 8.a. Pada review digunakan untuk jangkauan suhu antara $0^{\circ} \mathrm{C}$ sampai dengan $150^{\circ} \mathrm{C}$, seperti ditunjukkan gambar 8.b. Keluaran tegangan maksimum LM 35 adalah sekitar 1,5 V.

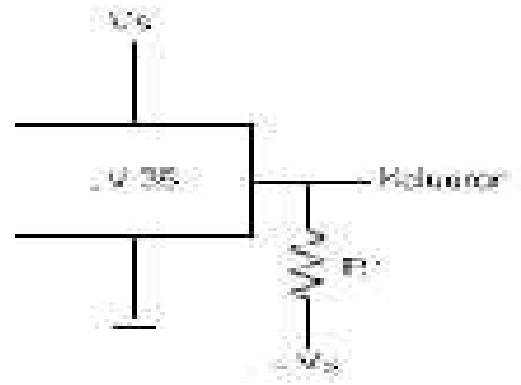

(a)

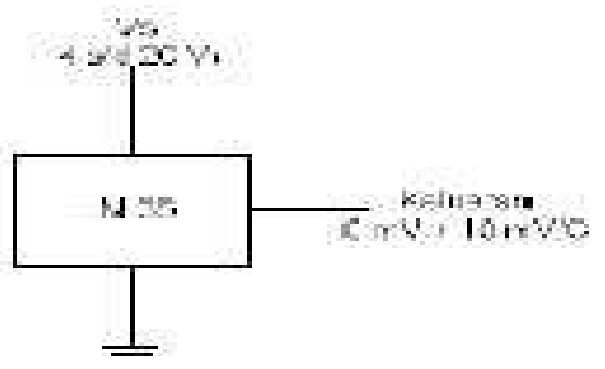

(b)

Gambar 8. (a).Konfigurasi LM35 untuk jangkauan suhu maksimum [4]

(b).Konfigurasi dasar LM35 [4] 


\subsubsection{Pengkondisi Sinyal}

Rangkaian pengkondisi sinyal ini merupakan rangkaian penguat tegangan dengan menggunakan penguat operasional tak membalik seperti yang ditunjukkan pada gambar 9 .

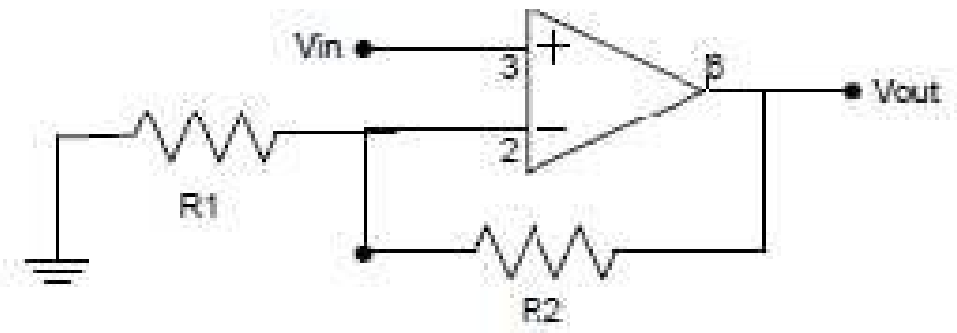

Gambar 9. Pengkondisi sinyal

Tegangan keluaran maksimum yang diinginkan adalah $5 \mathrm{~V}$, sedang tegangan masukan pengkondisi sinyal yang merupakan tegangan keluaran sensor hanya memiliki nilai maksimum sebesar $1,5 \mathrm{~V}$, sehingga diperlukan penguatan sebesar :

$$
A=V_{\text {out }} / V_{\text {in }}=5 / 1,5=3,333 \mathrm{~A}
$$

Sehingga diperoleh nilai R1 dan R2 sebagai berikut :

$$
\mathrm{V}_{\text {out }} / \mathrm{V}_{\text {in }}=(\mathrm{R} 2 / \mathrm{R} 1)+1=3,333
$$

Selanjutnya diambil nilai R1 sebesar 2,2 K Ohm, dan R2 sebesar 5,13 K Ohm.

\subsubsection{Pengubah Analog ke Digital (ADC)}

ADC pada rancangan ini digunakan untuk mengubah masukan analog keluaran pengkondisi sinyal menjadi data digital 8 bit. Tipe ADC yang digunakan ADC 0804 pada mode kerja free running. Rangkaian free running ADC 0804 ditunjukkan pada gambar 10 .

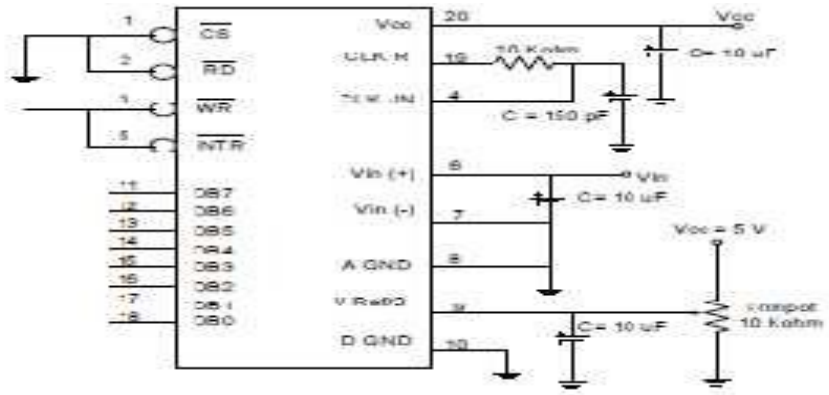

Gambar 10 Rangkaian free running ADC [1] 


\subsubsection{Pengubah Data Paralel Menjadi Data Serial UART dengan Mikrokontroler AT89C51}

\subsubsection{Perangkat Keras}

Data 8 bit keluaran dari pengubah analog ke digital (ADC) 8 bit menjadi masukan mikrokontoller untuk diubah menjadi data serial UART dengan menggunakan mikrokontroler AT89C51. Rangkaian ini ditunjukkan oleh gambar 11 di bawah ini.

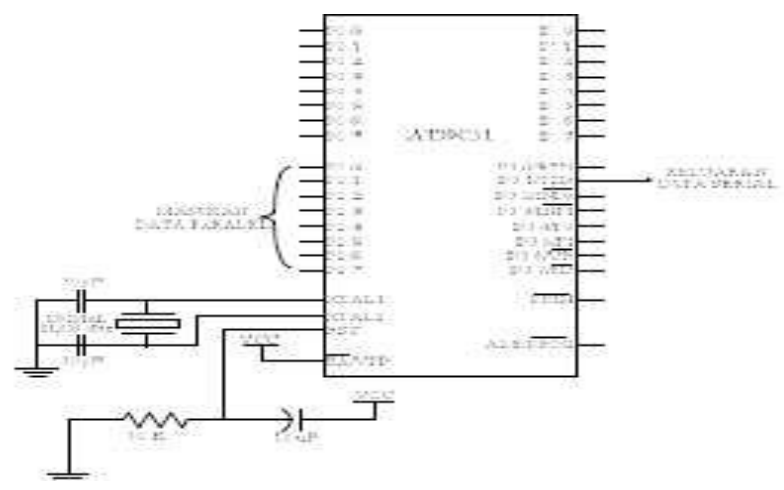

Gambar 11. Sistem minimum AT89C51

\subsubsection{Perangkat Lunak}

Diagram alir (flowchart) program ditunjukkan pada gambar 12.

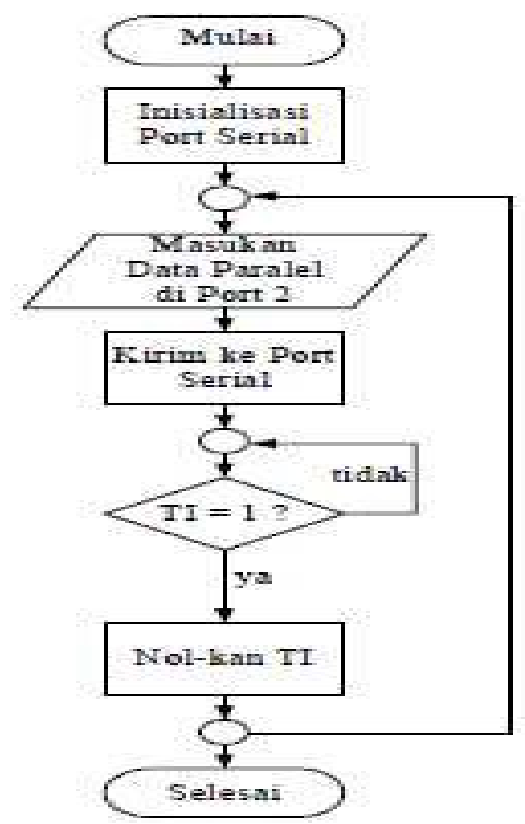

Gambar 12. Diagram alir program mikrokontroler 


\subsubsection{Modulator Pengunci Pergeseran Frekuensi (Frequency Shift Keying/FSK)}

Untuk mengirimkan bit-bit digital maka diperlukan suatu sistem modulasi digital yang dapat mengkonversi bit-bit tersebut ke dalam bentuk sinyal analog. Modulasi digital yang dipakai ialah sistem FSK dengan menggunakan rangkaian terintegrasi tipe TCM3105.

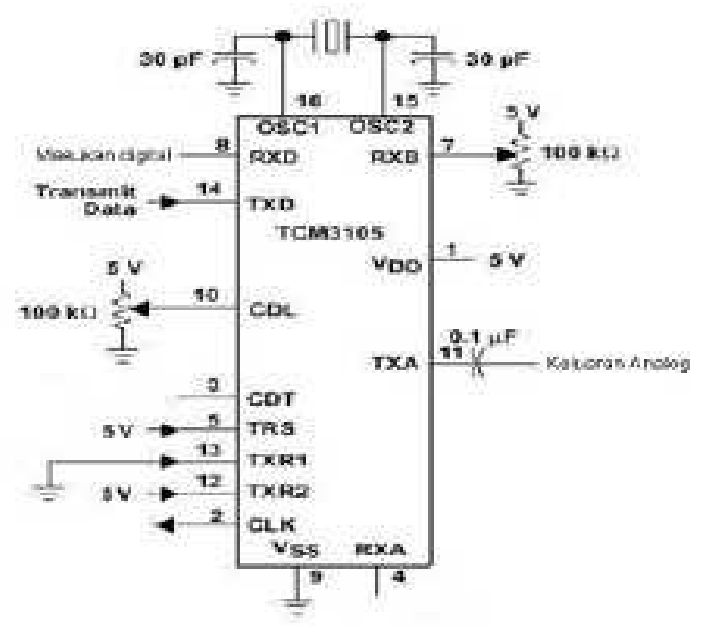

Gambar 13. Rangkaian modulator FSK dengan TCM3105

\subsubsection{Pembangkit Sinyal Penanda}

Sinyal penanda digunakan sebagai indicator untuk membedakan sinyal informasi dengan sinyal lainnya, sehingga hanya sinyal informasi yang diinginkan yang dapat diterima oleh stasiun penerima. Adapun gambar rangkaian pembangkit sinyal penanda ini ditunjukkan oleh gambar 14 .

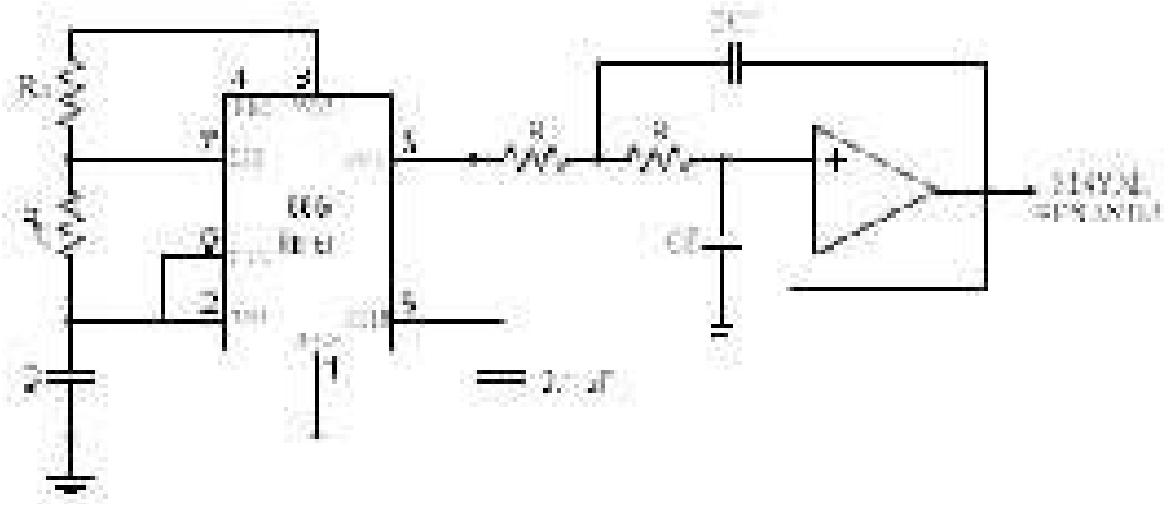

Gambar 14. Pembangkit sinyal penanda 


\subsubsection{Penjumlah Sinyal}

Penjumlah sinyal ini digunakan untuk menjumlahkan sinyal penanda dan sinyal FSK sebelum masuk ke pemancar FM. Rangkaiannya adalah sepert ditunjukkan gambar 15.

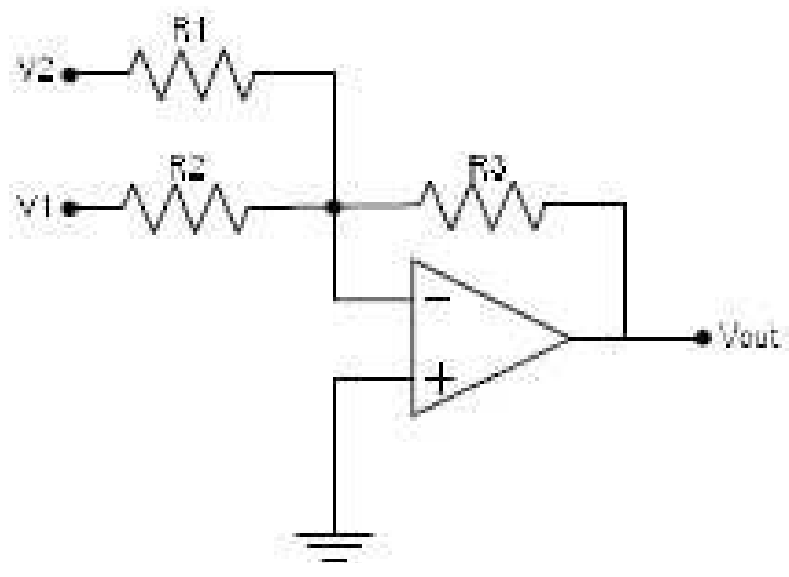

Gambar 15. Penjumlah sinyal [4] Nilai-nilai R1 = R2 = R3 sehingga keluarannya tanpa penguatan dan membalik [5].

\subsubsection{Pemancar Modulasi Frekuensi}

Pemancar FM ini terdiri dari tiga bagian utama, yaitu osilator, penyangga (buffer) dan penguat daya.

\subsubsection{Osilator}

Osilator yang digunakan adalah osilator LC dengan bentuk rangkaian seperti ditunjukkan gambar 16.

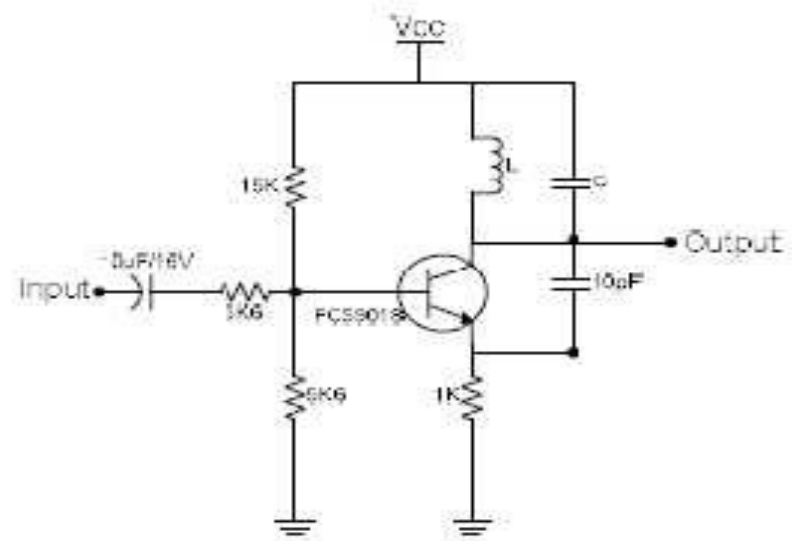

Gambar 16. Osilator pemancar FM [4] 


\subsubsection{Rangkaian Penyangga}

Penyangga berfungsi untuk menstabilkan frekuensi dan/atau amplitudo osilator akibat dari pembebanan tingkat selanjutnya. Pada review ini menggunakan penguat kelas A sebagai penyangga seperti ditunjukkan gambar 17. Osilator yang dilengkapi dengan penyangga biasanya disebut sebagai exciter. Exciter sebenarnya sudah bisa dipakai sebagai pemancar FM dengan daya yang relatif kecil.

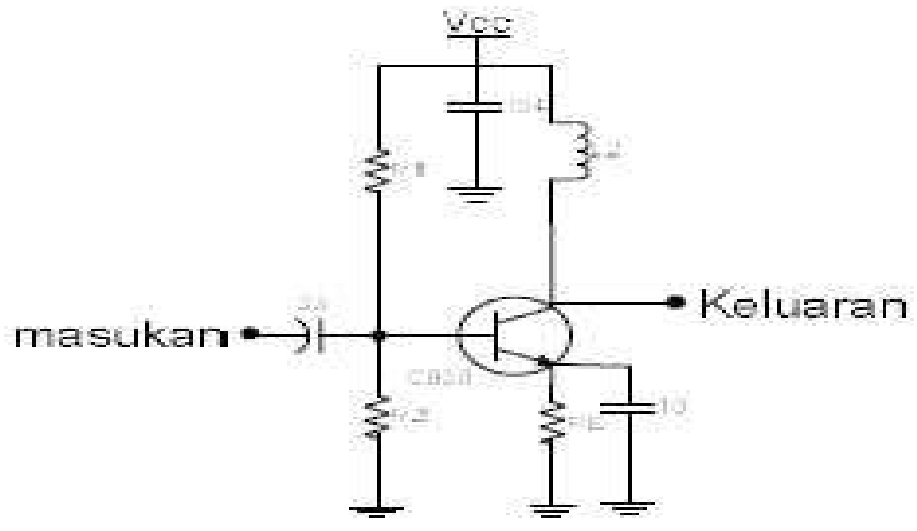

Gambar 17. Rangkaian penyangga

\subsubsection{Penguat Daya}

Sinyal yang didapat dari exciter masih relatif lemah. Untuk mendapatkan daya yang lebih besar dibutuhkan penguat daya frekuensi radio. Pada review ini rangkaian penguat daya yang digunakan adalah dua tingkat, yang pertama menggunakan transistor C2053, dan diikuti dengan C1971, seperti terlihat dalam gambar18.

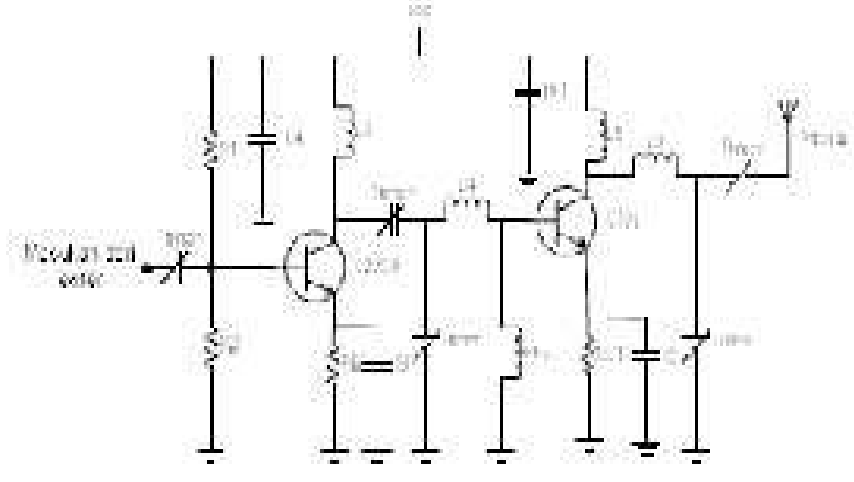

Gambar 18. Penguat daya 


\subsubsection{Antena Yagi}

Sebuah elemen antena yagi terdiri dari 3 elemen utama yaitu 1 elemen reflektor, 1 elemen driven, dan 3 elemen direktor.

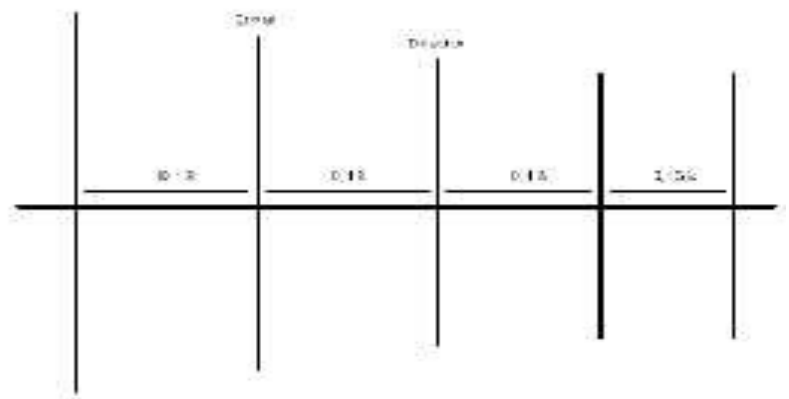

Gambar 19. Antena yagi

\subsection{Bagian Penerima}

Bagian penerima ini terdiri dari penerima FM, PLL, tapis pelewat frekuensi rendah $3 \mathrm{KHz}$, demodulator FSK, gerbang NAND dan RS 232. Adapun diagram untuk bagian penerima ini ditunjukkan oleh gambar 20 .

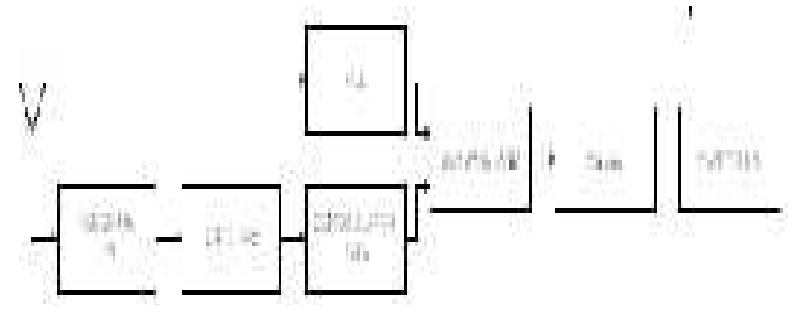

Gambar 20. Blok diagram penerima

\subsubsection{Penerima FM}

Penerima FM ini menggunakan tuner dan sebuah IC LA 1260 sebagai IC demodulator FM. Tuner yang digunakan adalah tuner build up, yang menghasilkan sinyal IF, yang kemudian diolah oleh IC LA1260, rangkaian lengkap ditunjukkan oleh gambar 21. 


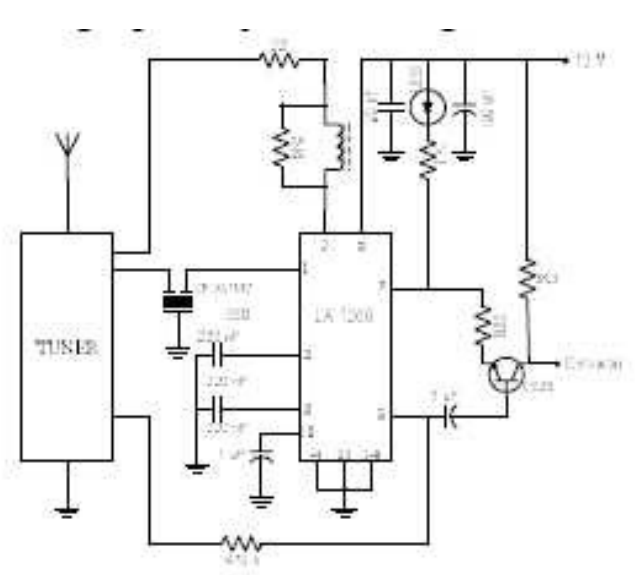

Gambar 21. Penerima FM [4]

\subsubsection{Tapis Pelewat Frekuensi Rendah $4 \mathrm{KHz}$}

Tapis ini digunakan untuk memisahkan sinyal informasi dari sinyal penanda, sebelum sinyal informasi yang berbentuk sinyal analog diubah menjadi digital oleh demodulator FSK. Tapis ini ditunjukkan oleh gambar 22. Nilai-nilai komponen yang digunakan pada tapis pelewat frek uensi rendah tersebut adalah Nilai $\mathrm{R}=3 \mathrm{kÙ}$ dan $\mathrm{C}=10 \mathrm{nF}$, sehingga nilai frekuensi cut off dapat dihitung ;

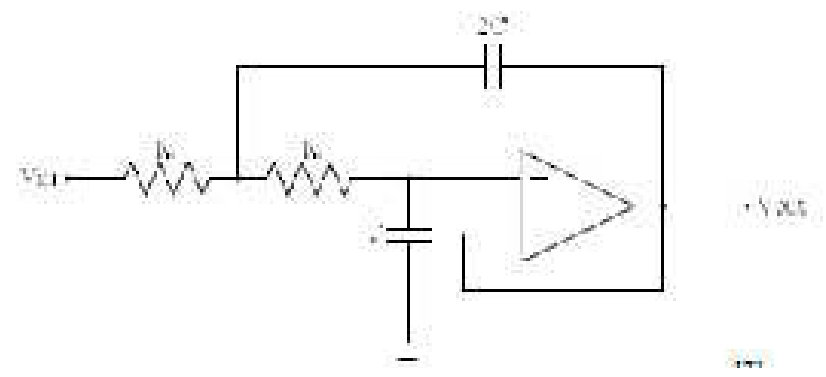

Gambar 22. Tapis pelewat frekunsi rendah

\subsubsection{Demodulator FSK}

Menurut standar CCITT untuk mengatur mode operasi penerimaan pada demodulator FSK yang menggunakan IC TCM3105 dapat dilihat pada Tabel.

Tabel 1. Mode operasi demodulator FSK pada TCM3105 


\begin{tabular}{|c|c|c|c|c|c|}
\hline \multirow[t]{2}{*}{ IRS } & \multirow[t]{2}{*}{ TXRI } & \multirow[t]{2}{*}{ TSR } & \multirow[t]{2}{*}{ Bandrate } & \multicolumn{2}{|c|}{ Frelacusi } \\
\hline & & & & mark & space \\
\hline I & E & 1 & 1200 & 1300 & 2100 \\
\hline$\overline{\mathrm{H}}$ & I & I & 75 & 390 & 450 \\
\hline L & I & H & 75 & 390 & 450 \\
\hline $\mathrm{H}$ & L & H & 800 & 1300 & 1700 \\
\hline E & 旦 & L & 1200 & 1300 & 2100 \\
\hline $\mathrm{H}$ & $\mathrm{H}$ & $L$ & 600 & 13,00 & $1, W$ \\
\hline L & H & H & $7 \overline{5}$ & 390 & 450 \\
\hline
\end{tabular}

Mode operasi tersebut digunakan untuk mengatur baudrate pada demodulatornya. Dalam penerimaan data menggunakan baudrate sebesar 1200 bps sehingga TRS, TXR1, dan TXR2 diberi masukan logika rendah (L). Atau TRS diberi masukan logika rendah (L), TXR1 diberi masukan logika tinggi (H) dan TXR2 diberi masukan logika rendah (L).

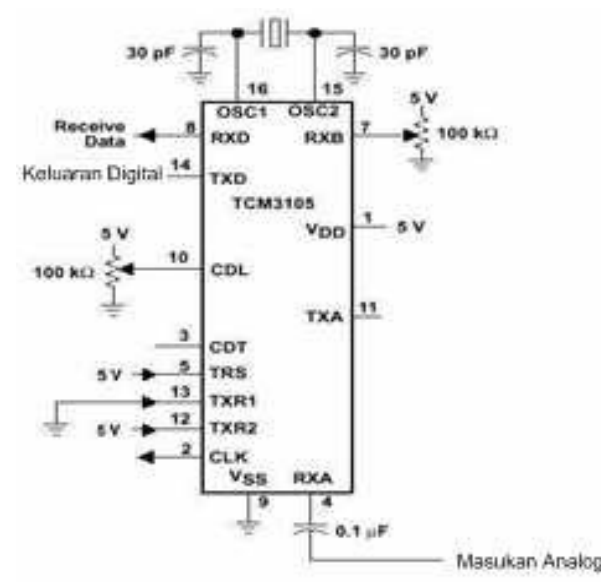

Gambar 23. Rangkaian lengkap demodulator FSK dengan IC TCM105 [4]

\subsubsection{Pendeteksi Sinyal Penanda}

Pendeteksi sinyal ini digunakan untuk mendeteksi sinyal yang diinginkan, sehingga pada saat sinyal yang diterima adalah sinyal informasi maka led akan menyala. 
Sedangkan untuk mengatur supaya led hanya menyala jika ada sinyal 58 KHz. Maka resistor variable pada pin 16 IC LA3361 perlu diset dengan cara memutarnya sampai nilai yang diinginkan diperoleh.

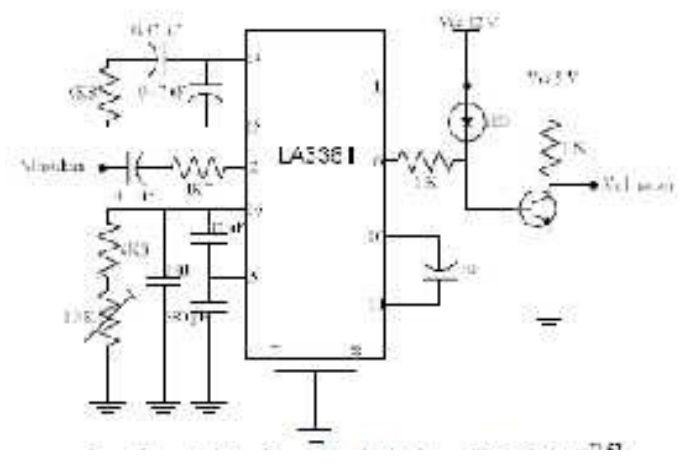

Gambar 24. Pendeteksi sinyal $58 \mathrm{KHz}[4]$

\subsubsection{Pengkondisi Penerimaan}

Pengkondisi penerimaan berfungsi untuk menonaktifkan data masukan saat tidak ada sinyal penanda. Keluaran dari demodulator FSK adalah data acak bila masukannya adalah sinyal acak. Hal ini tentunya akan mengganggu pada sistem penerima jika data acak tersebut dikenali sebagai informasi. Rangkaian gerbang AND digunakan untuk pengkondisi penerimaan.

Salah satu masukannya adalah dari PLL pendeteksi sinyal penanda. Bila dalam keadaan ada sinyal penanda, PLL terkunci fasa (lock) maka akan memberikan masukan tinggi. Masukan satunya lagi adalah dari keluaran demodulator FSK. Keluaran dari gerbang adalah data yang akan dimasukan pada RS232.

\subsubsection{RS232}

Bagian ini menggunakan rangkaian terintegrasi (IC) jenis MAX232, yang memang berfungsi untuk mengubah aras tegangan TTL menjadi aras tegangan RS232, dan sebaliknya. MAX232 menggunakan sistem komunikasi simplex sehingga difungsikan untuk mengubah dari aras tegangan logika TTL menjadi aras tegangan logika komputer (RS232). 


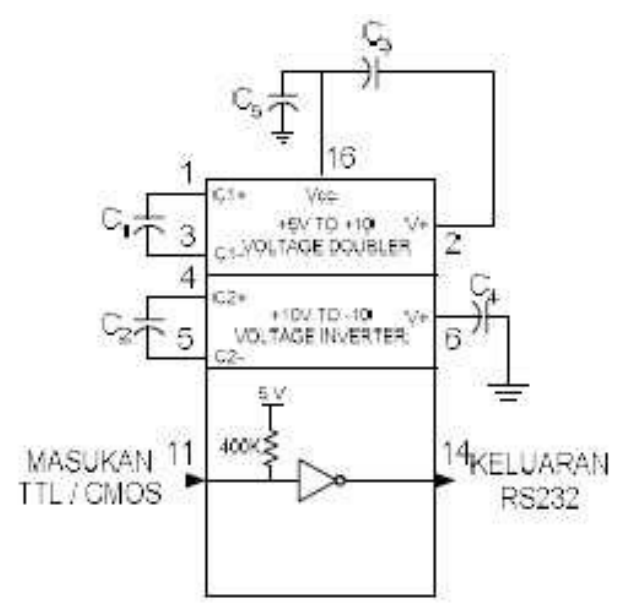

Gambar 25. Antarmuka serial RS232 dengan IC MAX232

\subsubsection{Program Penampil Suhu pada Komputer}

Data keluaran RS232 masuk ke komputer melalui port serial, yang kemudian akan diolah dengan menggunakan program Visual Basic 6. Untuk penerimaan data menggunakan perintah :

Data $=\operatorname{asc}($ MSComm1.Input $)$

Variabel data di atas sudah langsung dalam bentuk desimal sehingga langsung dapat diolah atau dikonversi menjadi suhu dengan perhitungan matematis sebagai berikut.

Vpenguat $=$ Data $*(5 / 255)$

Vsensor $=$ Vpenguat $*(1.5 / 5)$

suhu $=$ Vsensor / 0.01)

Vpenguat merupakan tegangan keluaran pengkondisi sinyal, merupakan hasil penguatan sebesar 5/1,5 kali dari tegangan sensor (Vsensor).Setiap $10 \mathrm{mV}$ atau $0,01 \mathrm{~V}$ menunjukkan nilai $1^{\circ} \mathrm{C}$.

\section{PENGUJIAN SISTEM}

\subsection{Pengujian Sensor Suhu LM35}

Sensor suhu yang digunakan adalah LM35, sensor ini dikonfigurasikan untuk dapat mendeteksi suhu antara $0^{\circ}$ sampai $150^{\circ}$ C. Sensor LM35 
menunjukkan bahwa setiap kenaikan $10 \mathrm{mV}$ mewakili kenaikan suhu $1^{\circ} \mathrm{C}$. Hasil pengukuran tegangan LM35 dan pengukuran suhu dengan termometer terlihat pada tabel 2 .

Tabel 2. Hasil Pengujian LM35 [5]

\begin{tabular}{|c|c|c|}
\hline $\begin{array}{c}\text { Suini } \\
\text { Lemometer } \\
\text { (WC) }\end{array}$ & $\begin{array}{l}\text { legungan } \\
\text { Kaliaran } \\
\text { LM 55 }\end{array}$ & $\begin{array}{l}\text { Konversi } \\
\text { Teyangas } \\
\text { ke Sulu dan } \\
\mathrm{LM} 35 \mathrm{CO}^{\circ}\end{array}$ \\
\hline 1 & 0.012 & 1.2 \\
\hline 5 & 0.058 & 5.1 \\
\hline 10 & $0.11:$ & 11.3 \\
\hline 15. & 0.156 & 16.6 \\
\hline 2n & 0.06 & 166 \\
\hline 25 & $0.2+1$ & 24.1 \\
\hline 30 & 0.25 & 25.4 \\
\hline s & $a<+\infty$ & $.4 \mathrm{C}$ \\
\hline 40 & $0.39:$ & 36.3 \\
\hline 45 & 0.441 & 4.1 \\
\hline $\bar{x}$ & 0.438 & -8.8 \\
\hline
\end{tabular}

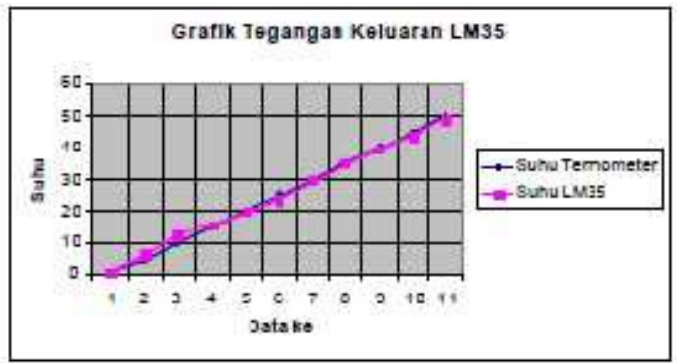

Gambar 27. Grafik perbandingan pengamatan suhu dengan termometer

\subsection{Pengujian perangkat lunak}

Pengujian ini dilakukan dengan menghubungkan semua blok dan mengaktifkannya. Kemudian keluaran RS232 dihubungkan ke port serial komputer. Jika semua alat (bagian pemancar dan penerima) menyala maka pendeteksi sinyal akan menyala sehingga akan mengkondisikan gerbang AND untuk mengaktifkan penerimaan data sehingga pada layar akan ditampilkan data seperti gambar 27. 


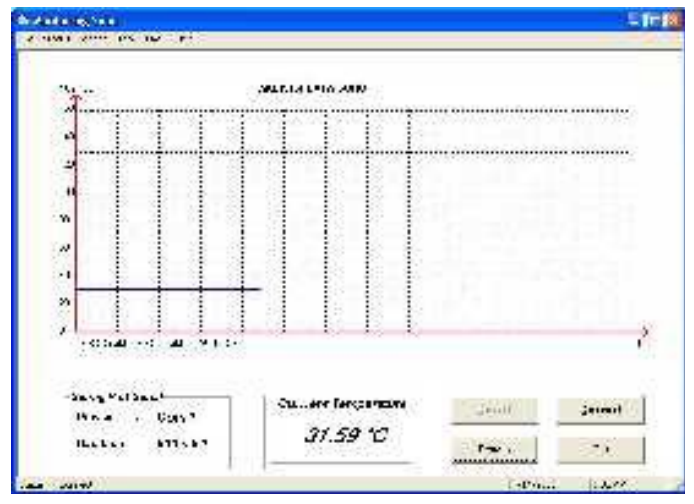

Gambar 28. Tampilan saat sinyal penanda terdeteksi [5]

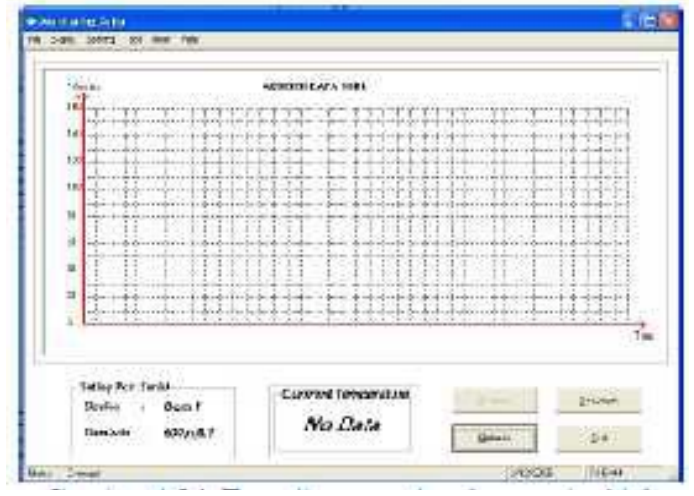

Gambar 29. Tampilan saat sinyal penanda tidak terdeteksi [4]

\section{KESIMPULAN}

Berdasarkan hasil penelitian dari beberapa peneliti , maka didapatkan halhal penting sebagai berikut :

1. Sensor suhu LM35 menghasilkan pengukuran yang berbeda dengan pengukuran termometer maksimum 1,20C.

2. Kelemahan sistem telemetri suhu yang dirancang antara lain suhu yang dapat diukur oleh sensor adalah antara 2 sampai $150^{\circ}$ Celsius, jangkauan pemancar hanya 700 meter, dan baudrate pada modem TCM3105 yang digunakan maksimal hanya 1200 bps. 


\section{DAFTAR PUSTAKA}

[1] Arif, Ronald. Perancangan Telemetri Suhu dengan Modulasi Digital On-Off Keying (OOK) - Modulasi Frekuensi (FM). Teknik Elektro Universitas Diponegoro.

[2] Murtianta, Budiardja. 2010. Modulator dan Demodulator FSK (Frequency Shift Keying). Teknik Elektro UKSW.

[3] Pahlanop, Boni. 2011. Prototipe Sistem Telemetri Berbasis Sensor Suhu dan Sensor Asap untuk Pemantauan Kebakaran Lahan. Fakultas MIPA Universitas Tanjungpura, Pontianak.

[4] Rifai, Januar. Perancangan Telemetri Suhu dengan Modulasi Digital FSK (Frequancy Shift Keying) - Modulasi Frekuensi. Teknik Elektro Universitas Diponegoro.

[5] Sukiswo. 2005. Perancangan Telemetri Suhu dengan Modulasi Digital FSKFM. Teknik Elektro Universitas Diponengoro . 